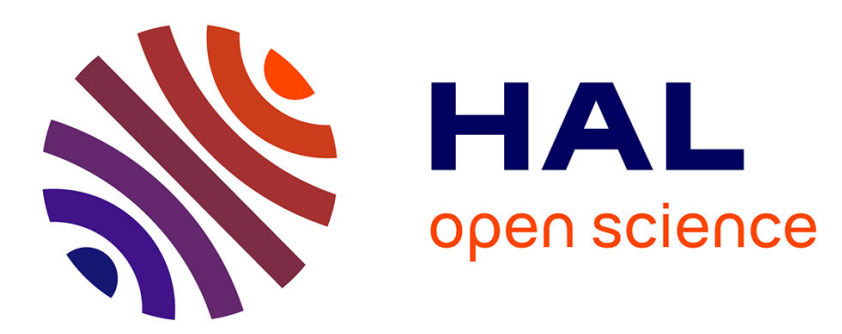

\title{
A new XPS/UPS study of the electronic structure of PdH0.6
}

\author{
L. Schlapbach, J.P. Burger
}

\section{To cite this version:}

L. Schlapbach, J.P. Burger. A new XPS/UPS study of the electronic structure of PdH0.6. Journal de Physique Lettres, 1982, 43 (8), pp.273-276. 10.1051/jphyslet:01982004308027300 . jpa-00232045

\section{HAL Id: jpa-00232045 https://hal.science/jpa-00232045}

Submitted on 1 Jan 1982

HAL is a multi-disciplinary open access archive for the deposit and dissemination of scientific research documents, whether they are published or not. The documents may come from teaching and research institutions in France or abroad, or from public or private research centers.
L'archive ouverte pluridisciplinaire HAL, est destinée au dépôt et à la diffusion de documents scientifiques de niveau recherche, publiés ou non, émanant des établissements d'enseignement et de recherche français ou étrangers, des laboratoires publics ou privés. 
Classification

Physics Abstracts

$71.20-78.70 \mathrm{D}$

\title{
A new XPS/UPS study of the electronic structure of $\mathbf{P d H}_{0.6}$
}

\author{
L. Schlapbach and J. P. Burger (*) \\ Laboratorium für Festkörperphysik ETH, CH-8093 Zürich, Switzerland \\ (*) Laboratoire de Physique des Solides $\left({ }^{* *}\right)$, Université de Paris-Sud, 91405 Orsay, France
}

(Reçu le 5 janvier 1982, accepté le 9 mars 1982)

\begin{abstract}
Résumé. - Nous avons étudié la structure électronique de $\mathrm{PdH}_{0,6}$ à $100 \mathrm{~K}$ au moyen de la photoémission en utilisant des sources de radiation $\mathrm{MgK} \alpha$ et $\mathrm{HeI}$, II. Nous observons dans $\mathrm{PdH}_{0,6}$ un déplacement de la bande d par rapport à $E_{\mathrm{F}}$ et une diminution de $N\left(E_{\mathrm{F}}\right)$. Contrairement à d'autres mesures, nous n'observons pas de bande d'émission aux environs de $5 \mathrm{eV}$. Par contre, nous voyons une faible émission à $8 \mathrm{eV}$ probablement due aux états induits par l'hydrogène. Le déplacement chimique du niveau de coeur $3 d_{5 / 2}$ est très faible $(+0,15 \pm 0,10 \mathrm{eV})$.
\end{abstract}

\begin{abstract}
We have studied the electronic structure of $\mathrm{PdH}_{0.6}$ at $100 \mathrm{~K}$ by means of photoelectron spectroscopy using $\mathrm{MgK} \alpha$ and HeI, II radiation. In $\mathrm{PdH}_{0.6}$ as compared to Pd, the d-band is shifted away from $E_{\mathrm{F}}$, and $N\left(E_{\mathrm{F}}\right)$ is considerably decreased. In contradiction to earlier investigations we do not observe a band around $5 \mathrm{eV}$. However, we see weak emission at $8 \mathrm{eV}$ probably related with the hydrogen induced states. The chemical shift of the $3 \mathrm{~d}_{5 / 2}$ core level is very small $(+0.15 \pm 0.10 \mathrm{eV})$.
\end{abstract}

At room temperature, $\mathrm{Pd}$ dissolves some hydrogen in the $\alpha$-phase $\left(\mathrm{PdH}_{0.01}\right)$ and forms at the equilibrium pressure of $\approx 10 \mathrm{mbar}$ the $\beta$-phase $\mathrm{PdH}_{0.6}$. At higher pressure the hydrogen content of the $\beta$-phase increases towards stoichiometric PdH [1].

Many band structure calculations were performed for $\mathrm{PdH}_{x}$ An overview on the different methods and the results was given recently by Switendick [2]. All the calculations have the following features in common, which can be tested experimentally :

1) The d-band of $\mathrm{Pd}$ is modified and shifted relative to $E_{\mathrm{F}}$. The density of states $N\left(E_{\mathrm{F}}\right)$ (one spin direction) at $E_{\mathrm{F}}$ decreases from $1.1 \mathrm{states} / \mathrm{eV}$ unit cell for $\mathrm{Pd}$ to 0.25 states $/ \mathrm{eV}$ unit cell in $\mathrm{PdH}[3]$.

2) A new band is formed about 7 to $8 \mathrm{eV}$ below $E_{\mathrm{F}}$. It is mainly derived from $\mathrm{s}$ and d states of Pd.

3) A very small charge transfer seems to occur.

The decrease of $N\left(E_{\mathrm{F}}\right)$ is in good agreement with results from specific heat and magnetic susceptibility measurements ([3] and references cited therein).

The electronic structure of $\mathrm{PdH}$ has been investigated by several groups by means of photoelectron spectroscopy using X-rays (XPS) or UV radiation (UPS) :

$\left.{ }^{(* *}\right)$ Laboratoire associé au Centre National de la Recherche Scientifique. 
Eastman et al. [4] exposed a Pd film at $350^{\circ} \mathrm{C}$ to $5 \times 10^{-6}$ torr of $\mathrm{H}_{2}$ and subsequently at room temperature to 170 torr $\mathrm{H}_{2}$ for $30 \mathrm{~min}$. and analysed it with UPS. An additional peak was detected $5.4 \mathrm{eV}$ below $E_{\mathrm{F}}$ and interpreted as the hydrogen induced band. No decrease of $N\left(E_{\mathrm{F}}\right)$ was observed. The authors do not indicate at which hydrogen pressure and sample temperature the analysis was made, but probably at room temperature in ultrahigh vacuum.

Antonangeli et al. [5] charged a bulk Pd sample electrochemically with hydrogen and analysed it with XPS. They observed additional states from 5.5 to $8 \mathrm{eV}$ which they related to the hydrogen induced states. No variation of $N\left(E_{\mathrm{F}}\right)$ was observed. The $\mathrm{Pd} 3 \mathrm{~d}_{5 / 2}$ core level is shifted from $334.8 \mathrm{eV}$ in $\mathrm{Pd}$ to $334.9 \mathrm{eV}$ in $\mathrm{PdH}$. Again, sample temperature and hydrogen pressure during the analysis are not indicated.

Veal et al. [6] and Gilberg et al. [7] attempted to see the hydrogen induced states at room temperature by means of XPS and X-ray emission spectroscopy but failed because the hydrogen escaped through the clean surface.

The discrepancies between the experimental results of different groups about the new states and between theory and experiment about $N\left(E_{\mathrm{F}}\right)$ led us to the reinvestigation of $\mathrm{PdH}$ by means of XPS and UPS.

The analysis was performed on a VG Escalab spectrometer using $\mathrm{MgK} \alpha(1253 \mathrm{eV}), \mathrm{HeI}$ $(21.2 \mathrm{eV})$ and $\mathrm{HeII}(40.8 \mathrm{eV})$ radiation. The analyser was set to give an instrumental resolution of $\approx 1.0 \mathrm{eV}$ for $\mathrm{MgK} \alpha$ and $\approx 0.2 \mathrm{eV}$ for $\mathrm{HeI}, \mathrm{II}$. $E_{\mathrm{F}}$ and the binding energy scale were calibrated on $\mathrm{Au}$. Apart from the valence band we also investigated the $\mathrm{Pd} 3 \mathrm{~d}_{5 / 2,3 / 2}$ core levels. The working pressure was $6 \times 10^{-11} \mathrm{mbar}$ before the inlet of He and before the desorption of hydrogen started.

Pd foils (0.125 mm thick, $99.99 \%$, Goodfellow), mounted on Cu sample holders, were cleaned in the spectrometer by $\mathrm{Ar}^{+}$bombardment and subsequently annealed at $300{ }^{\circ} \mathrm{C}$ for 1 hour. After the analysis of the Pd metal it was transferred into the high pressure autoclave of the spectrometer and kept for $30 \mathrm{~min}$. at 15 bar hydrogen at room temperature. Before releasing the high pressures the sample was cooled to $100 \mathrm{~K}$ and then transferred on a cooled support to the precooled sample manipulator and analysed at $100 \mathrm{~K}$.

The pressure in the analysing chamber rose to $5 \times 10^{-9} \mathrm{mbar} \mathrm{H}_{2}$ and dropped to $5 \times 10^{-10} \mathrm{mbar}_{2}$ within $10 \mathrm{~min}$. A pressure increase was also observed when the power of the X-ray source was set to $200 \mathrm{~W}$ or more. Thus the XPS spectra were measured at 50 and $100 \mathrm{~W}$. The residual gas was analysed with a mass spectrometer. All pressure variations were due to $\mathrm{H}_{2}$ or $\mathrm{He}$ (He lamp on). The peaks at the masses 16,18 and $28\left(\mathrm{O}_{2}, \mathrm{H}_{2} \mathrm{O}, \mathrm{CO}\right)$ showed the same intensity as at $6 \times 10^{-11}$ mbar total pressure.

The contamination of the sample was checked by the analysis of the 1s levels of carbon and oxygen before and after the hydrogenation and again after desorption. No carbon could be detected. The oxygen $1 \mathrm{~s}$ level overlaps with the $\mathrm{Pd} 3 \mathrm{p}_{3 / 2}$ peak. However, from the comparison of the peak areas divided by theoretical cross section of the $3 \mathrm{~d}_{5 / 2}$ and $3 \mathrm{p}_{3 / 2}$ peaks we conclude that within the accuracy of the background subtraction and of the cross sections no oxygen was present.

From the thermodynamic properties of the $\mathrm{Pd}-\mathrm{H}$ system [1] we estimate that we charged our samples to the concentration slightly above $\mathrm{PdH}_{0.6}$. At $100 \mathrm{~K}$ the equilibrium pressure should be of the order of $10^{-10} \mathrm{mbar}_{2}$ and the kinetics very slow. Thus we estimate that our samples, after some initial desorption during the first $10 \mathrm{~min}$., correspond to $\mathrm{PdH}_{0.6}$.

At temperatures above $150 \mathrm{~K}$ and ultrahigh vacuum all our $\mathrm{PdH}_{0.6}$ samples with clean surfaces desorbed very quickly their hydrogen at least within the escape depth of XPS $(\approx 25 \AA$ for the $\mathrm{VB}$ and $\mathrm{Pd} 3 \mathrm{~d}_{5 / 2}$ ). Electrolytically charged samples kept the hydrogen under similar conditions, but their surface was contaminated.

In figure 1 the HeI and HeII spectra are shown for $\mathrm{PdH}_{0.6}$ at $100 \mathrm{~K}$ and $5 \times 10^{-10} \mathrm{mbar}_{2}$ (curves A), for $\mathrm{PdH}_{x}$ after the beginning of the desorption $\left(\approx 200 \mathrm{~K}, 1 \times 10^{-6} \mathrm{mbar} \mathrm{H}_{2}\right.$, curve B) 
and for Pd at the end of the desorption $\left(250 \mathrm{~K}, 5 \times 10^{-7}\right.$ mbar, curves C). In $\mathrm{PdH}_{0.6}$ the d-band is displaced relative to $E_{\mathrm{F}}$ and accordingly $N\left(E_{\mathrm{F}}\right)$ is rather small. No peaks appear between 5 and $6 \mathrm{eV}$. With increasing desorption (B) the displacement becomes smaller and at the end of the desorption $(\mathrm{C})$ the d-band begins at $E_{\mathrm{F}}$ and $N\left(E_{\mathrm{F}}\right)$ is large. The HeI and HeII spectra of $\mathrm{PdH}_{0.6}(\mathrm{~A})$ as compared to those of $\mathrm{Pd}(\mathrm{C})$ exhibit a weak additional emission around $8 \mathrm{eV}$.

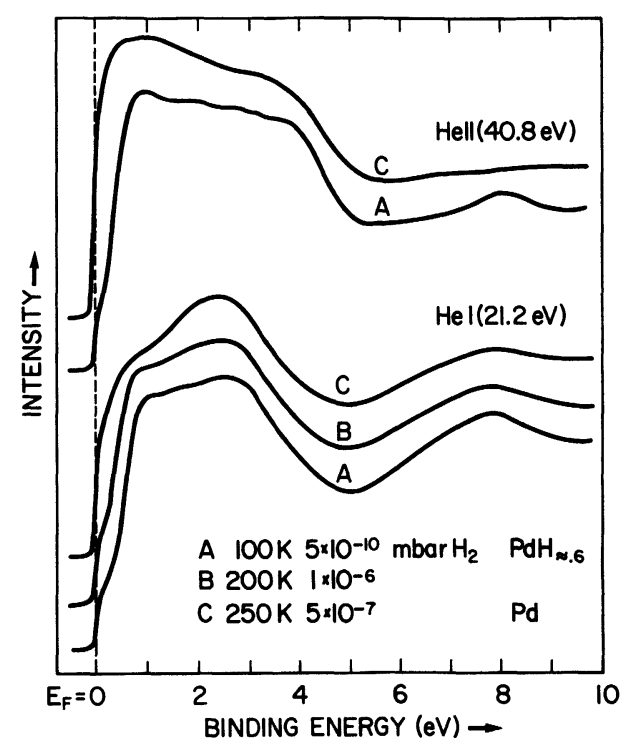

Fig. 1. - UPS spectra of $\mathrm{PdH}_{x}$ before (A), during (B) and at the end (C) of hydrogen desorption.

The XPS valence band spectrum of $\mathrm{PdH}_{0.6}$ (Fig. 2) as compared to that of $\mathrm{Pd}$ shows the same features as the He spectra show : A small displacement of the d-band relative to $E_{\mathrm{F}}$ together with the decrease of $N\left(E_{\mathrm{F}}\right)$, no peak between 5 and $6 \mathrm{eV}$, but some additional emission around $8 \mathrm{eV}$. The d-band intensity of $\mathrm{PdH}_{0.6}$ at $3 \mathrm{eV}$ is slightly larger than in $\mathrm{Pd}$. The chemical shift of the $3 \mathrm{~d}_{5 / 2}$ core level (Fig. 2$)$ to higher binding energy is very small $(0.15 \pm 0.10 \mathrm{eV})$.

In conclusion, we have shown that the XPS and UPS spectra of $\mathrm{PdH}_{0.6}$ differ from those of $\mathrm{Pd}$ in the following points : The d-band of $\mathrm{PdH}_{0.6}$ is displaced relative to $E_{\mathrm{F}}$ and $N\left(E_{\mathrm{F}}\right)$ is considerably reduced in agreement with theory. A weak emission around $8 \mathrm{eV}$ is probably due to the

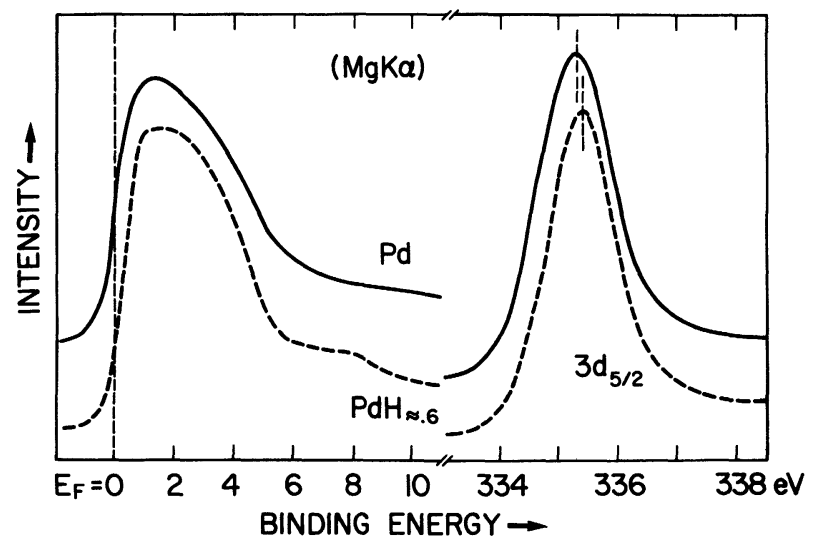

Fig. 2. - XPS spectra of the valence band and of the $3 \mathrm{~d}_{5 / 2}$ core level of $\mathrm{PdH}_{0.6}$ and Pd at $100 \mathrm{~K}$. 
hydrogen induced states. We do not observe, however, hydrogen induced states between 5 and $6 \mathrm{eV}$. The $3 \mathrm{~d}_{5 / 2}$ core level is shifted not more than $0.15 \pm 0.10 \mathrm{eV}$.

Acknowledgments. - We should like to thank P. Brack for technical assistance, H. C. Siegmann for continued interest and the Swiss National Science Foundation for financial support.

\section{References}

[1] Wicke, E., Brodowsky, H. and Züchner, H., in Topics in Appl. Physics, Hydrogen in Metals, G. Alefeld, ed. (Springer) 1978, Vol. 29.

[2] Switendick, A. C., Z. Phys. Chem. N.F. 117 (1979) 89.

[3] Gupta, M. and Freeman, A. J., Phys. Rev. B 17 (1978) 3029.

[4] Eastman, D. E., Cashion, J. K. and Switendick, A. C., Phys. Rev. Lett. 27 (1971) 35.

[5] Antonangeli, F., Balzarotti, A., Bianconi, A., Burattini, E., Perfetti, P. and Nistico, N., Phys. Lett. 55A (1975) 309 and Solid State Commun. 21 (1977) 201.

[6] Veal, B. W., Lam, D. J. and Westlake, D. G., Phys. Rev. B 19 (1979) 2856.

[7] Gilberg, E., Extended Abstracts, Int. Conf. on the Physics of X-Ray Spectra, National Bureau of Standards, Gaithersburg, Maryland, 1976. 